\title{
The Spatial Distribution Characteristics of IT Enterprises in Shanghai Caohejing Hi-Tech Park: Take the 24 Buildings as Example
}

\author{
Long-fei Chen \\ School of Economics of Shanghai University, Shanghai, China
}

\section{Email address:}

chenlf0222@hotmail.com

\section{To cite this article:}

Long-fei Chen. The Spatial Distribution Characteristics of IT Enterprises in Shanghai Caohejing Hi-Tech Park: Take the 24 Buildings as Example. Earth Sciences. Vol. 4, No. 6, 2015, pp. 223-227. doi: 10.11648/j.earth.20150406.11

\begin{abstract}
Due to the increasing returns to scale and the external economic effect, the industrial cluster, as a kind of geographical phenomenon in the process of industrial development, is the inevitable product of the process of economic development in the world. This paper selects 24 buildings in Caohejing Hi-Tech Park(CHJ, Shanghai, China) as a sample. Using the Gini coefficient method, from the three dimensions of 976 companies in the 24 buildings-industry types, company types, labor types, we found that the electronic information industry cluster in CHJ region has been initially apparent. Electronic information manufacturing industry (two digit industries such as C39) and its supporting services (such as the three digit industry F517, L721 etc.) has begun to take shape; and the corresponding industry talent reserves have also been able to support the electronic information industry chain of $\mathrm{CHJ}$ region of operation; private and foreign-funded enterprises have very strong economic vitality and thus the strong momentum of development CHJ areas; the quantity of SOE is not much but is strength.
\end{abstract}

Keywords: IT Enterprises, GINI Coefficient, Spatial Distribution, Industrial Agglomeration

\section{Introduction}

CHJ is located in the southwest of Shanghai, bounded by Guilin Road (East), Xin Jing Hong (West), Caobao Road (South) and Puhuitang (North), whose planning area is about 14.28 square kilometers. There are more than 2500 China-invested and overseas-funded high-tech enterprises in CHJ, of which 500 were set up by the world's top 126 . By 2014 , its annual sales revenue is up to 285.2 billion, of which the service sector contributing 190.8 billion; Gross Regional Product (GDP) is about 97 billion, 78.5 billion of industrial output, total imports and exports 12 billion U.S. dollars; all the given data proves $\mathrm{CHJ}$ one of the top development zone in the nationwide.

As an integrant phenomenon in its process of industry evolution, industrial agglomeration has obvious regionality. A successful agglomeration in electronic information industry will set a good example in the development of the high-tech industry [1,2], even of the national economy.

Economic geography, new economic geography and institutional factors will produce obvious impact toward industrial agglomeration [2]. Shanghai possesses all the factors above-developed infrastructure, huge amounts of enterprises, excellent human resources, advanced opening and reasonable local protection.

On the basis of Jiang-yong LU and Zhi-gang TAO [3], An-bo WU and Lin-yan SUN found that industries with high degree of agglomeration will have a high level of technique intensity, low profit margin and big non-SOE proportion, which are the main characteristics of $\mathrm{CHJ}$.

This study selects 976 companies in 24 independent buildings of $\mathrm{CHJ}$ as the sample. We then analyze the spatial distribution characteristics of IT enterprises in CHJ from three dimensions - industry types, labor types and business forms, applying the Spatial Gini Coefficient.

\section{The Calculation of the Spatial Gini Coefficient and Its Judgment Criterion of Agglomeration Degree}

\subsection{The Calculation of the Spatial Gini Coefficient}

The Spatial Gini Coefficient measures the degree of spatial agglomeration, which was put forward by Krugman in 1991. 
The expression of the Spatial Gini Coefficient is:

$$
G_{k}=\sum_{i=1}^{n} \frac{\left|X_{i}-X\right|}{\left[\sum_{i=1}^{n} X_{i}+(n-2) X\right]}
$$

Where $G_{k}$ is the Spatial Gini Coefficient, $\mathrm{k}$ is a certain category - industry types, labor types and business forms; $X_{i}$ is the amount of certain type of enterprises in building $\mathrm{i}$; $\mathrm{X}$ is the density of certain type of enterprises; $n$ is the amount of buildings in our sample.

\subsection{The Judgment Criterion of Agglomeration Degree}

According to the United Nations, we rate the Spatial Gini Coefficient into six grades, and we set a threshold value (0.382) in judging with whether it was agglomerating obviously.

$G_{k}<0.2$ : Grade 1 (G1), uniform distribution, no agglomeration;

$0.2 \leq G_{k}<0.3$ : Grade $2(\mathrm{G} 2)$, relative uniform distribution, slight agglomeration;

$0.3 \leq G_{k}<0.382$ : Grade 3-(G3-), relatively uneven distribution, unobvious agglomeration;

$0.382 \leq G_{k}<0.4$ : Grade $3+(\mathrm{G} 3+)$, relatively uneven distribution, obvious tending agglomeration;

$0.4 \leq G_{k}<0.5$ : Grade 4 (G4), uneven distribution, obvious agglomeration;

$G_{k} \geq 0.5$ : Grade 5 (G5), extremely uneven distribution and super agglomeration.

\section{The Spatial Distribution \\ Characteristics of IT Enterprises in the 24 Sample Buildings in CHJ}

\subsection{One-Digit Industry Perspective}

Based on the $<$ National Economy Industry Classification Standard $>$ and the main business of 976 enterprises in $\mathrm{CHJ}$, certain classifications are made as followed.

As one-digit-industry statistics showed, the five industries with the most amount of companies-Wholesale and Retail Trade (F), Manufacturing Industry (C), Software and Information Technology Services (I), Scientific Research and Technical Services (M), Leasing and Business Services (L) - occupy $86.17 \%$ of all the samples. Taking Building Industry (E) and Financial Industry $(F)$ into consideration, we get:

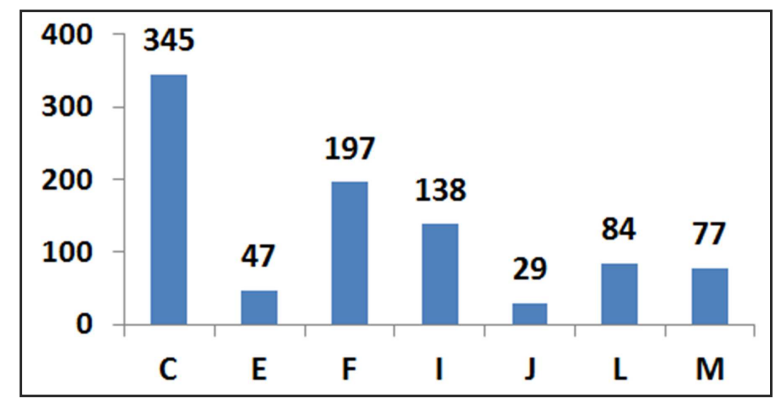

Fig. 1. The amounts of companies in the seven industries in CHJ.
Then we use the one-digit-industry data above to calculate our Spatial Gini Coefficient.

Table 1. The Gini coefficients of one-digit industries.

\begin{tabular}{llllllll}
\hline $\begin{array}{l}\text { Industry } \\
\text { Code }\end{array}$ & C & E & F & I & J & L & M \\
\hline GINI & 0.5525 & 0.3378 & 0.5053 & 0.5115 & 0.3261 & 0.5248 & 0.4670 \\
Grade & G5 & G3- & G5 & G5 & G3- & G5 & G4 \\
\hline
\end{tabular}

It's easy to get agglomerating degree series by ranking the values in the table: $\mathrm{C}>\mathrm{L}>\mathrm{I}>\mathrm{F}>\mathrm{M}>\mathrm{E}>\mathrm{J}$.

\subsection{Two-Digit Industry Perspective}

In the same way, we can gain our coefficients of all the two-digit industries.

Table 2. The Gini coefficients of two-digit industries.

\begin{tabular}{|c|c|c|c|}
\hline Industry Name & $\begin{array}{l}\text { Industry } \\
\text { Code }\end{array}$ & GINI & Grade \\
\hline Textile Industry & $\mathrm{C} 17$ & 0.2250 & G2 \\
\hline $\begin{array}{l}\text { Chemical Raw Materials and Chemical } \\
\text { Products Manufacturing }\end{array}$ & $\mathrm{C} 26$ & 0.3194 & G3- \\
\hline Rubber and Plastic Products & $\mathrm{C} 29$ & 0.1827 & G1 \\
\hline $\begin{array}{l}\text { General Equipment Manufacturing } \\
\text { Industry }\end{array}$ & $\mathrm{C} 34$ & 0.3856 & $\mathrm{G} 3+$ \\
\hline $\begin{array}{l}\text { Special Equipment Manufacturing } \\
\text { Industry }\end{array}$ & $\mathrm{C} 35$ & 0.4358 & G4 \\
\hline Automobile Industry & $\mathrm{C} 36$ & 0.1917 & G1 \\
\hline $\begin{array}{l}\text { Electrical Machinery and Equipment } \\
\text { Manufacturing }\end{array}$ & $\mathrm{C} 38$ & 0.4684 & G4 \\
\hline $\begin{array}{l}\text { Computers, Communications and other } \\
\text { Electronic Equipment Manufacturing } \\
\text { Industry }\end{array}$ & $\mathrm{C} 39$ & 0.5069 & G5 \\
\hline Instrument Manufacturing & $\mathrm{C} 40$ & 0.2948 & G2 \\
\hline Housing Industry & E47 & 0.1389 & G1 \\
\hline Civil Engineering Construction & E48 & 0.2500 & G2 \\
\hline Construction and Installation & E49 & 0.1927 & G1 \\
\hline $\begin{array}{l}\text { Building Decoration and other } \\
\text { Construction }\end{array}$ & $\mathrm{E} 50$ & 0.3109 & G3- \\
\hline Wholesale Business & F51 & 0.5042 & G5 \\
\hline Retailing & F52 & 0.1732 & G1 \\
\hline $\begin{array}{l}\text { Telecommunications, Broadcasting } \\
\text { and TV Transmission and Satellite } \\
\text { Services }\end{array}$ & I63 & 0.1417 & G1 \\
\hline The Internet and Related Services & I64 & 0.3750 & G3- \\
\hline $\begin{array}{l}\text { Software and Information Technology } \\
\text { Services }\end{array}$ & I65 & 0.4748 & G4 \\
\hline Monetary and Financial Services & J66 & 0.1065 & G1 \\
\hline Capital Markets Services & J67 & 0.3657 & G3- \\
\hline Business Services & L72 & 0.5296 & G5 \\
\hline $\begin{array}{l}\text { Research and Experimental } \\
\text { Development }\end{array}$ & M73 & 0.2837 & G2 \\
\hline Special Technical Services & M74 & 0.4132 & G4 \\
\hline $\begin{array}{l}\text { Science and Technology } \\
\text { Popularization and Application } \\
\text { Services }\end{array}$ & M75 & 0.3826 & G3+ \\
\hline
\end{tabular}

\subsection{Three-Digit Industry Perspective}

Similarly, we get some weighted three-digit-industry coefficients: 
Table 3. The Gini coefficients of three-digit industries.

\begin{tabular}{llll}
\hline Industry Code & F517 & L721 & M732 \\
\hline GINI & 0.4190 & 0.3750 & 0.2344 \\
Grade & G4 & G3- & G2 \\
\hline
\end{tabular}

Till now, we conclude that the electronic information industry chain has been established, mainly in collaboration with C39, I65, F517, L721 and M732. However, there still exists a broad development space for CHJ's R\&D ability.

Referring to $<$ Electronic information industry classification annotations (2005-2006) >, let's portray an integrated electronic information industry chain:

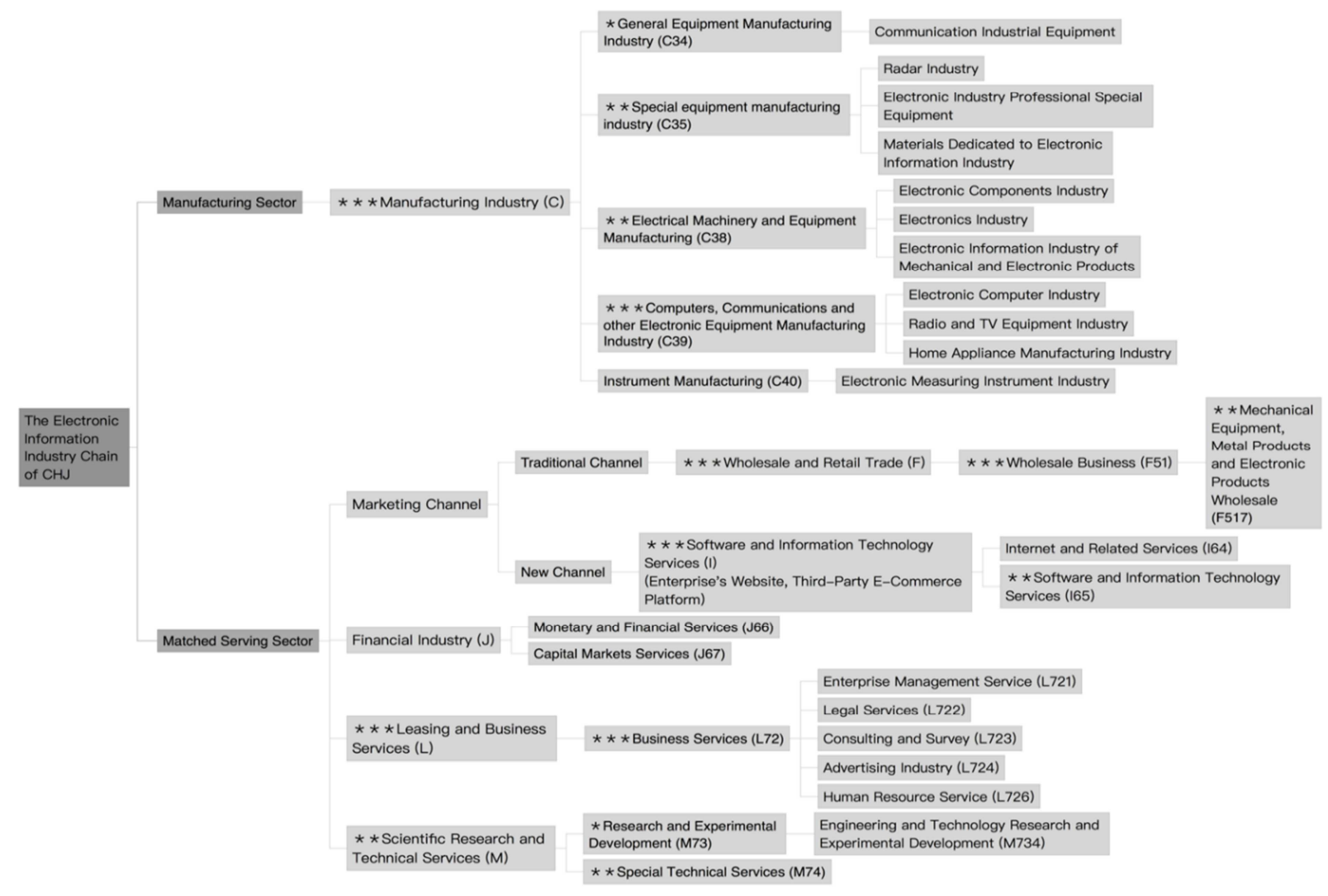

Fig. 2. The Electronic industrial chain in $\mathrm{CHJ}$.

Added Symbol * represents higher degree of Chinese-Foreign Equity Joint Ventures $>$, we classify all the agglomeration.

\subsection{Careers Style Perspective}

Referring to the $<$ Classification of the People's Republic of China $>$, especially the definitions and the characteristics of all the BigClassNames in that reference, we also made some statistics.

Same with the calculation of the Spatial Gini Coefficient in the perspective of different-digit industries, we compute that coefficient with all aspects of careers.

Table 4. The Gini coefficients of different occupations.

\begin{tabular}{llll}
\hline $\begin{array}{l}\text { Career } \\
\text { Types }\end{array}$ & $\begin{array}{l}\text { Professional } \\
\text { and Technical } \\
\text { Personnel }\end{array}$ & $\begin{array}{l}\text { Social Production } \\
\text { and Life Service } \\
\text { Personnel }\end{array}$ & $\begin{array}{l}\text { Manufacturing } \\
\text { and Related } \\
\text { Personnel }\end{array}$ \\
\hline GINI & 0.5899 & 0.5105 & 0.5446 \\
Grade & G5 & G5 & G5 \\
\hline
\end{tabular}

\subsection{Business Forms Perspective}

According to Chinese <Companies Law of the People's Republic of China $>$, $<$ The Law of the PRC on companies into three types - SOE, Joint Ventures and Private Enterprises.

Further, we explore the distributions of different types of companies in all the sample buildings.

Private enterprises and joint ventures are distributed in almost every sample building, and they occupy the majority room. On the contrary, SOEs are few and far between and are mainly distributed in few buildings.

Then we calculate our Spatial Gini Coefficients.

Table 5. The Gini coefficients of three types of companies.

\begin{tabular}{llll}
\hline Type of Enterprises & Private Enterprises & SOEs & Joint Ventures \\
\hline GINI & 0.5616 & 0.2060 & 0.6359 \\
Grade & 5 & 2 & 5 \\
\hline
\end{tabular}

SOEs are uniformly distributed and show a slight agglomeration. However, private enterprises and joint ventures are extremely uneven distribution and show a super agglomeration. The amount and the distribution of private enterprises and joint ventures show that $\mathrm{CHJ}$ has a powerful economic vitality, a strong developing momentum and a high degree of opening. 


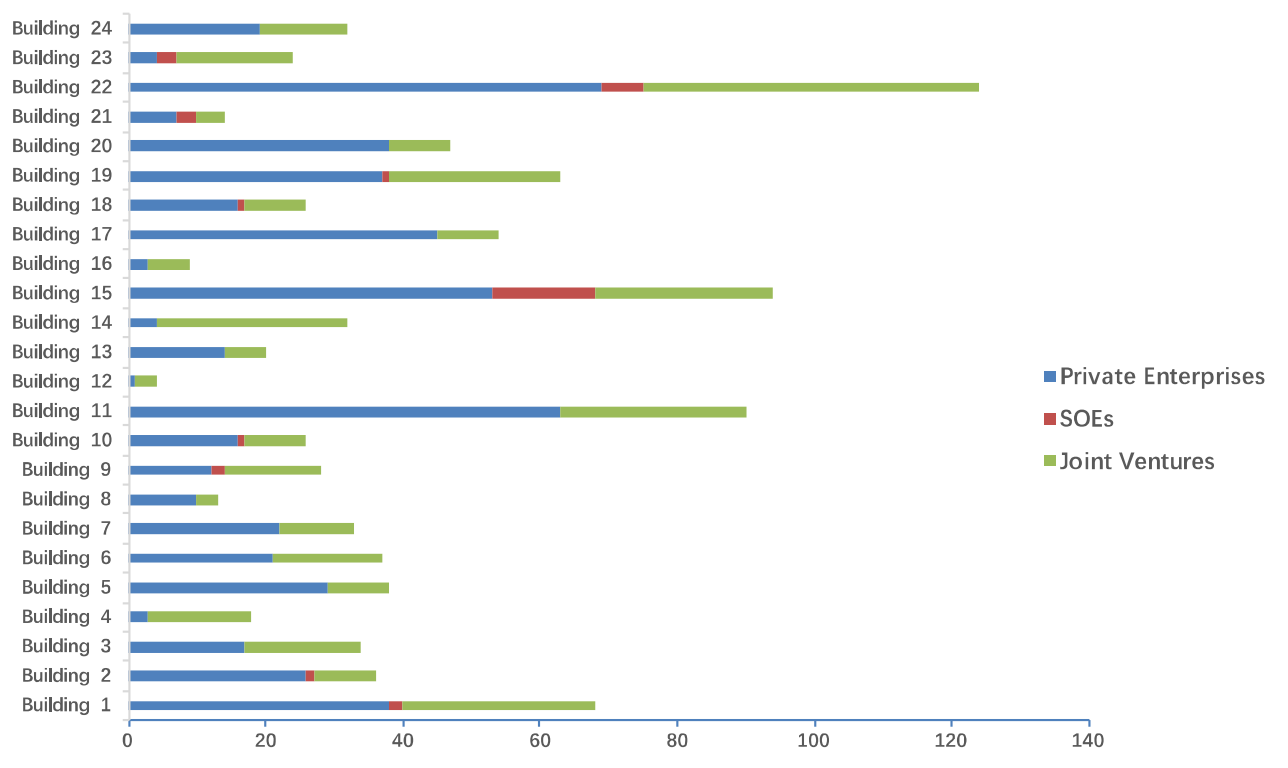

\section{Conclusion}

In conclusion, $\mathrm{CHJ}$ has established an integrated industrial cluster chain with pillar industries, key industries and supporting industries, and that chain has a potential of continuously booming development.

The electronic information industry chain, the pillar of $\mathrm{CHJ}$, is composed of two sectors-manufacturing sector and its matched serving sector. The manufacturing sector is mainly concentrated in PC, integrated circuit, electronics and communications equipment, etc. And the matched serving sector is referring to software and IT services, e-commerce platform, capital market services, business services, research and service outsourcing, etc.

However, our data also describe a possibility of further development.

Professional and Technical Personnel, Social Production and Life Service Personnel and Manufacturing and Related Personnel have become the mainstays of the chain. Meanwhile, high value-added modern service talents are beginning to take shape. And our data show a fact that $\mathrm{CHJ}$ has a big potential of the top talents' agglomeration.

Private Enterprises and Joint Ventures have a huge developing momentum and they drive the development of $\mathrm{CHJ}$ powerfully. SOEs are relatively rare and dispersive, but are very strong. It's unadvisable to set a fixed model for the three business forms. A negative list as the Shanghai Free Trade Zone carried out may help $\mathrm{CHJ}$ to reach a more effective market.

\section{Acknowledgement}

This research was finally supported by General Project of National Social Science Fund(13BGL154) and Innovation
Program of Shanghai Municipal Education Commission (12YS019).

\section{References}

[1] Yue-gang CHEN, Yan WU, Ru-xi GAO. Empirical Research on the Shanghai Industry Cluster in the Central of City[J]. SCIENCE \& TECHNOLOGY PROGRESS AND POLICY, 2009, 26(8): 37-41.

[2] Zi-long WANG, Qing-mei Tan, Xiao-di XU. The Metrical Method and Empirical Studies of High-tech Industry Agglomeration Level[J]. STUDIES IN SCIENCE OF SCIENCE, 2006, 24(5): 706-714.

[3] Hong-jiao YANG, Lin-yan SUN, Dong-han LIANG. Trends and Determinants of China's Hi-tech Industrial Agglomeration Degree _ take manufacture of electronic and communication equipment for example [J]. STUDIES IN SCIENCE OF SCIENCE, 2009, 27(9): 1335-1343.

[4] Jiang-yong LU, Zhi-gang TAO. Chinese Manufacturing Industry Agglomeration and International Comparison[J]. Economic Research Journal, 2006, (03).

[5] Xiu-jing BI, Ming-feng WANG, Jian LI. Agglomeration and Suburbanization: A Study on the Spatial Distribution of Software Industry and Its Evolution in Metropolitan Shanghai[J]. Acta Geographica Sinica, 2011, 66(12): 1682-1694.

[6] JESUS FELIPE, JOHN McCOMBIE. Agglomeration Economies, Regional Growth, and the Aggregate Production Function: A Caveat Emptor for Regional Scientists[J]. Spatial economic analysis, 2012, 7(4): 461-484.

[7] Ming-hua LU, Li LI. The spatial distribution of electronic information industries and its value chain parts in Beijing [J]. Geographical Research, 2012, 31(10): 1861-1871. 
[8] Yan WANG, Yan XU. Chinese High Technology Industry Agglomeration and Spatial Spillover Effect Research[J]. Modern Management Science, 2013, (1): 3-5.

[9] Chen CHEN, Fa-hui WNG, Chun-liang XIU. The Relationship Between the Spatial Distribution of Commercial Networks and Street Centrality in Changchun[J]. Economic Geography, 2013, 33(10): 40-47.

[10] Miao ZHANG. Investigation of a Coupling Model of Coordination between Modern Service Industry Cluster and Regional Industry Transfer- Taking Wanjiang City Belt as an Example[J]. Forum on Science and Technology in China, 2014, (3): 111-117.
[11] Qi YE. The Coordinative Effects and Development Tendency of China's Regional Industrial Transfer [J]. Contemporary Economy \& Management, 2014, (3):111-117.

[12] Ze-bin WU, Jin LI. SPATIAL CONCENTRATION OF JIANGXI'S INDUSTRY BASED ON REGIONAL GINI COEFFICIENT [J]. Resources \& Industries, 2014, 16(6): 100-103.

[13] Wen ZHANG, Li ZHANG, Jia-qiu WANG. Study on spatial distribution pattern of Shenzhen enterprises [J]. Science of Surveying and Mapping, 2015, 40(9): 65-68. 